
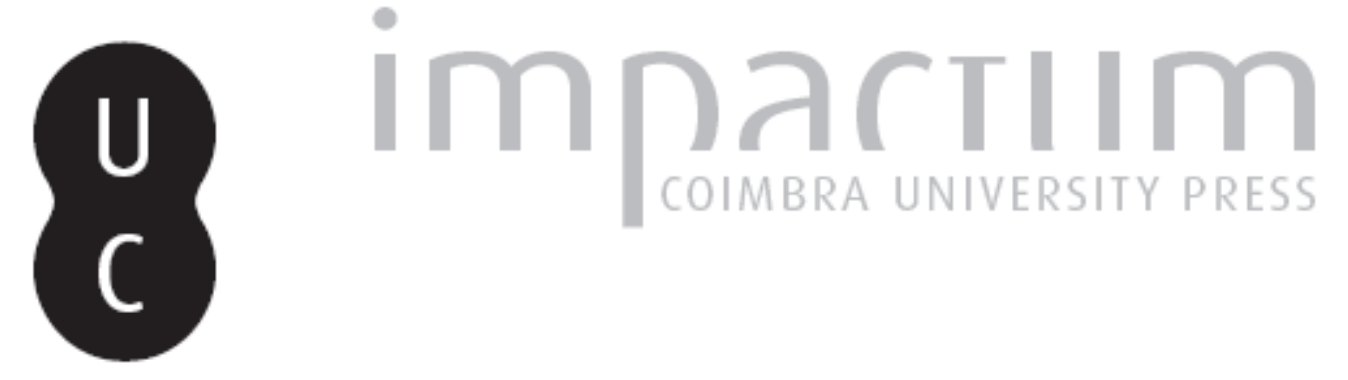

\title{
Notes on a new kind of art
}

\section{Autor(es): Moura, Leonel}

Publicado por: Centro de Literatura Portuguesa; Imprensa da Universidade de Coimbra

URL persistente:

URI:http://hdl.handle.net/10316.2/37792

DOI:

DOI:http://dx.doi.org/10.14195/2182-8830_3-1_11

Accessed : $\quad$ 26-Apr-2023 11:14:55

A navegação consulta e descarregamento dos títulos inseridos nas Bibliotecas Digitais UC Digitalis, UC Pombalina e UC Impactum, pressupõem a aceitação plena e sem reservas dos Termos e Condições de Uso destas Bibliotecas Digitais, disponíveis em https://digitalis.uc.pt/pt-pt/termos.

Conforme exposto nos referidos Termos e Condições de Uso, o descarregamento de títulos de acesso restrito requer uma licença válida de autorização devendo o utilizador aceder ao(s) documento(s) a partir de um endereço de IP da instituição detentora da supramencionada licença.

Ao utilizador é apenas permitido o descarregamento para uso pessoal, pelo que o emprego do(s) título(s) descarregado(s) para outro fim, designadamente comercial, carece de autorização do respetivo autor ou editor da obra.

Na medida em que todas as obras da UC Digitalis se encontram protegidas pelo Código do Direito de Autor e Direitos Conexos e demais legislação aplicável, toda a cópia, parcial ou total, deste documento, nos casos em que é legalmente admitida, deverá conter ou fazer-se acompanhar por este aviso.

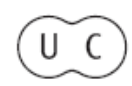




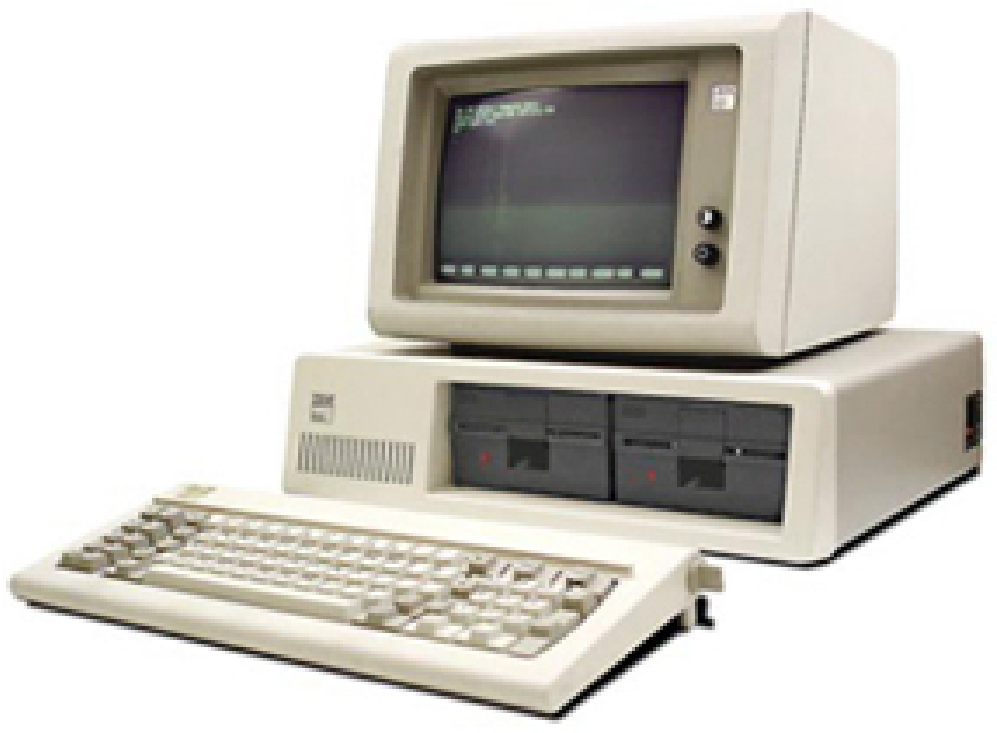

Vol. 3.1 (2015)

ISSN 2182-8830

'Artes, Média e Cultura Digital'

Paulo Silva Pereira e Pedro Serra (orgs.) 


\section{Notes on a New Kind of Art}

\section{LEONEL MOURA}

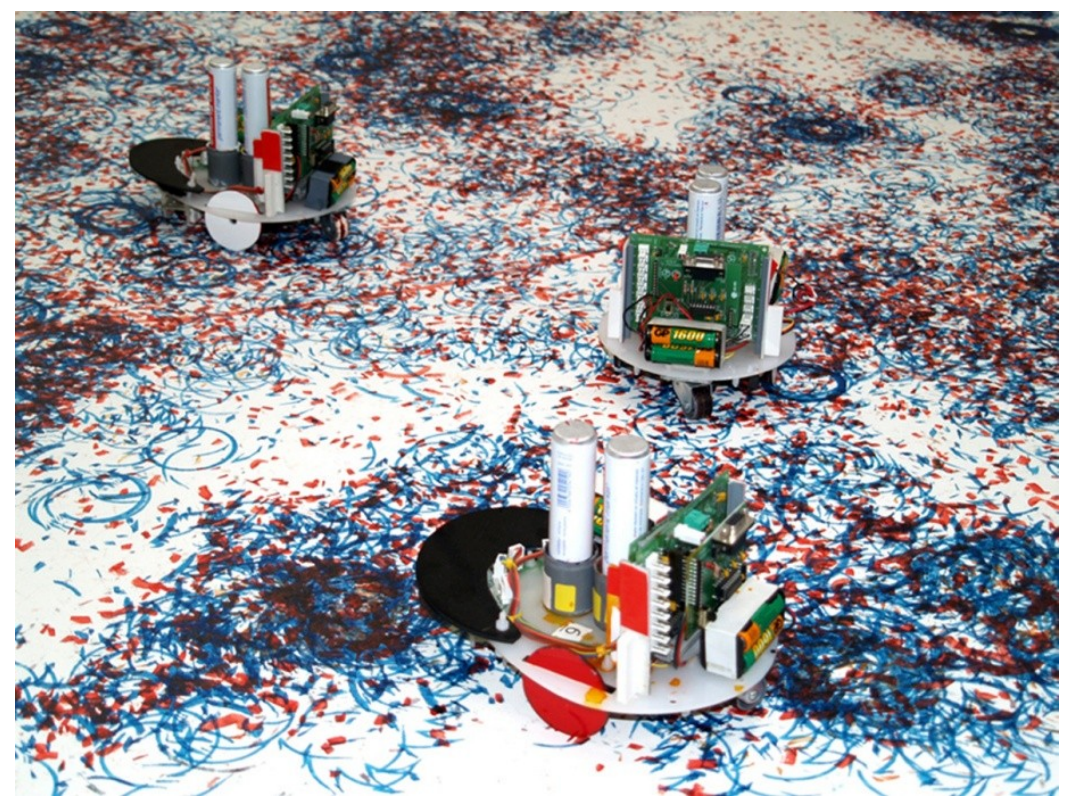

Figure 1. A swarm of ant-like robots, 2003. C Leonel Moura.

\section{Introduction}

I started working with robots applied to art around the turn of the century. Aiming at the most possible autonomy of the process, they were the next logical step after experimenting with algorithms confined to the computer environment. I was never interested in "digital art". The first experiences, with an ant algorithm running on a computer connected to a robotic arm [fig. 1], showed the potential for a machine to create its own drawings and paintings as a kind of artificial creativity.

Artsbot, a swarm of art robots produced in 2003, demonstrate that, when equipped with a set of simple rules combined with the input of sensors, robots can generate unique compositions independent from the human that starts the process. Such machines should not be seen as mere tools or devices for human predetermined aesthetic creations, as they are, at least partially, autonomous, and the result of their actions is unpredictable. Additionally, if randomness is an essential component of the process the resulting artwork cannot be described as random since recognizable patterns emerge from a fuzzy background. 
The claim that these works represent a new kind of art, the art of machines, may be controversial in the context of the mainstream art world. But, actually, it is inscribed in the global evolution of robotics and artificial intelligence towards a greater autonomy of machines. Art announces what is about to arrive.

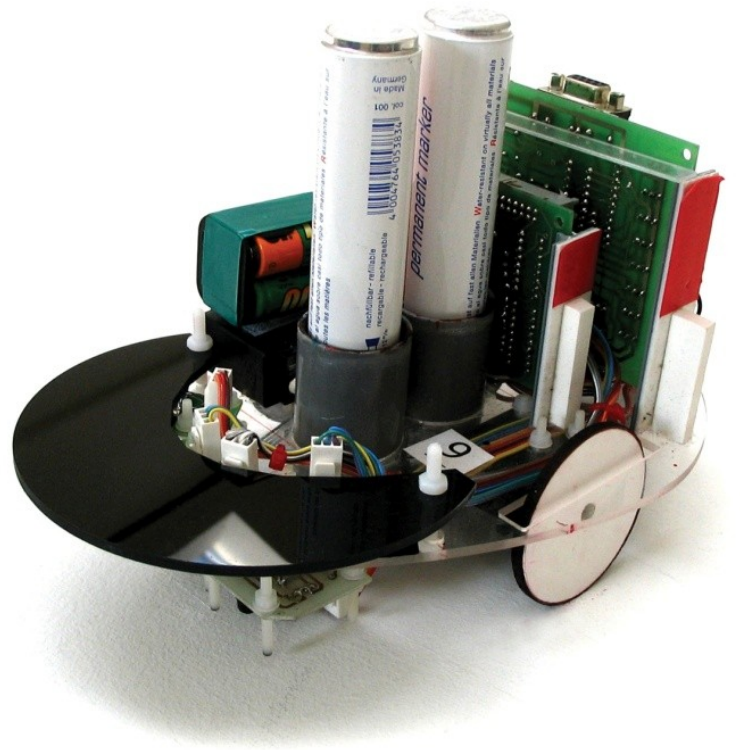

Figure 2. Ant-like robot, 2003. (C) Leonel Moura.

\section{Technical description of Artsbot robots}

The basic architecture of each robot contains three components: the sensors, the controller and the actuators. The sensors receive signals from the environment, which are processed by the microcontroller in order to command the actuators.

The sensors are of two kinds: those that receive the signal from the key environmental variable chosen, which is color, and those that perceive the proximity of obstacles.

Each color sensor is composed by one LED (Light-Emitting Diode) for each RGB color plus a fourth LED directed to White. The function of each LED is to measure the intensity of reflected light.

There are four proximity sensors on the robot's front. They consist of an IR emitter/receptor that produces a signal which is proportional to the distance from a white surface. Hence, the bounding barriers of the terrarium where robots evolve must be white. Since solar light may interfere with the 
sensors, robots should function in an artificial light setting. The range of distances perceived by this type of sensor is 1 to $15 \mathrm{~cm}$.

The controller is an on-board PIC 16F876 from Microchip, which reads signals from sensors, processes them according to a program and transmits the result to the actuators. The program is uploaded into the robot's chip, prior to each run, through the serial interface of a PC. This program is developed based on the PC graphic interface, consisting of a flowchart where test blocks for sensors and actuators are combined according to a certain sequence that can obviously be changed whenever wanted. Each test block compares a given variable with a previously defined control parameter and executes an "IF...THEN" rule.

The actuators consist of two servomotors producing movement by differential traction based on velocity control and one servomotor for manipulating the two pens that execute the action of painting. The latter is commanded by a signal analogous to the one sent to traction motors but, in this case, an angular position control is used.

The "warm" colors correspond to an intensity $<128$, encompassing yellow, red and green, whilst "cold" covers blue, violet and rose.

The chassis consists of an oval 20x15 cm platform, moved by 3 wheels and carrying two pens. Each robot is $12.5 \mathrm{~cm}$ tall and weighs $750 \mathrm{~g}$. Their lifetime with 8 AA batteries is 4 to 5 hours.

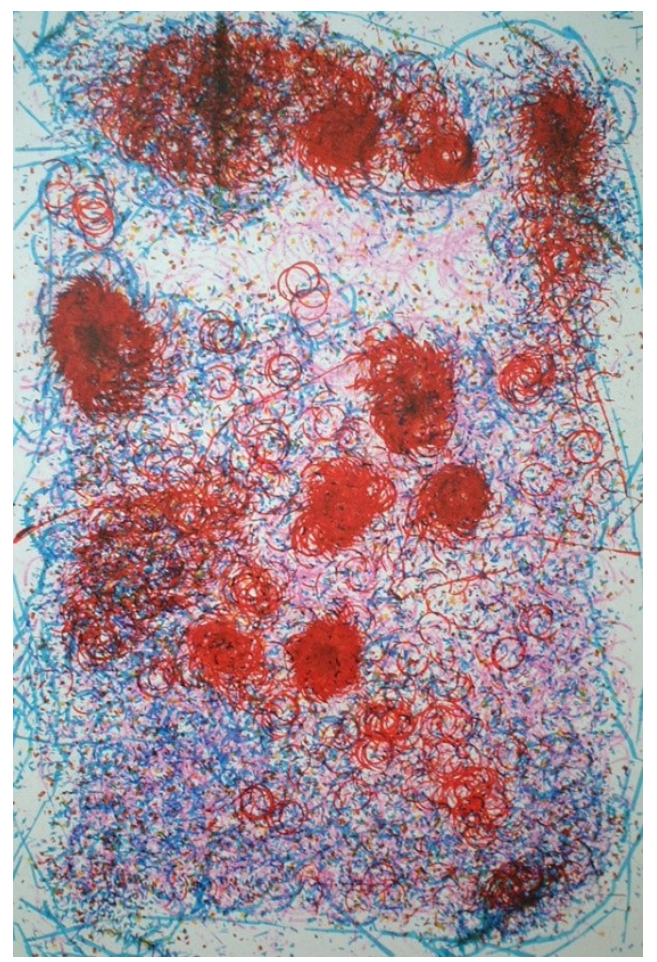

Figure 3. 010304, 2004, acrylic on canvas, $195 \times 130 \mathrm{~cm}$. C Leonel Moura. 


\section{Collective behavior of the robots}

The results of the experiment are prone to pass the Turing Test for intelligent machines. In fact, it is not possible to distinguish the paintings from human hand-made art.

The case to be made by the proposed approach is that creativity emerges in the set of robots as a consequence of self-organization, driven by their interaction with the environment. Actually, the random walk of each robot is only interrupted by the "appeal" of a certain color spot, trace or patch that was previously left in the canvas by another robot. Given that the robot only 'sees' a limited region of the canvas, if no color is detected in that region, it follows its path, putting down a mark of its passage only in the case that its random number generator produces a value that exceeds a given threshold. In statistics language, each one of the outcomes of the experiment is regarded as the realisation of a Random Function (RF), i.e., as a Regionalized Variable (RV). The RF is defined as the infinite set of dependent random variables $\mathrm{Z}(\mathrm{u})$, one for each location $\mathrm{u}$ in a certain area A. In this case, the area A is canvas, and the random variable is discrete, taking only three nominal color values - "Warm", "Cold" and "White". The underlying feedback process leads to the spatial dependency of the random variables and explains why clusters are usually formed in most of the RF instances. These instances are the mapping of the RV onto the canvas, depicting its hybrid structural/random constitutive fundamental nature.

The collective behavior of the set of robots evolving on a canvas (the terrarium that limits the space of the experience), is governed by the gradual increase of the deviation-amplifying feedback mechanism, and the progressive decrease of the random action, until the latter is practically completely eliminated. During the process the robots show an evident behavior change as the result of the "appeal" of color, triggering a kind of excitement not observed during the initial phase characterized by the random walk.

This is due to the stigmergy interaction between the robots, where one robot in fact reacts to what other robots have done. According to Grassé (1959), stigmergy is the production of certain behaviors in agents as a consequence of the effects produced in the local environment by a previous action of other agents.

Thus, the collective behavior of the robots is based on randomness, emergence and stigmergy. 


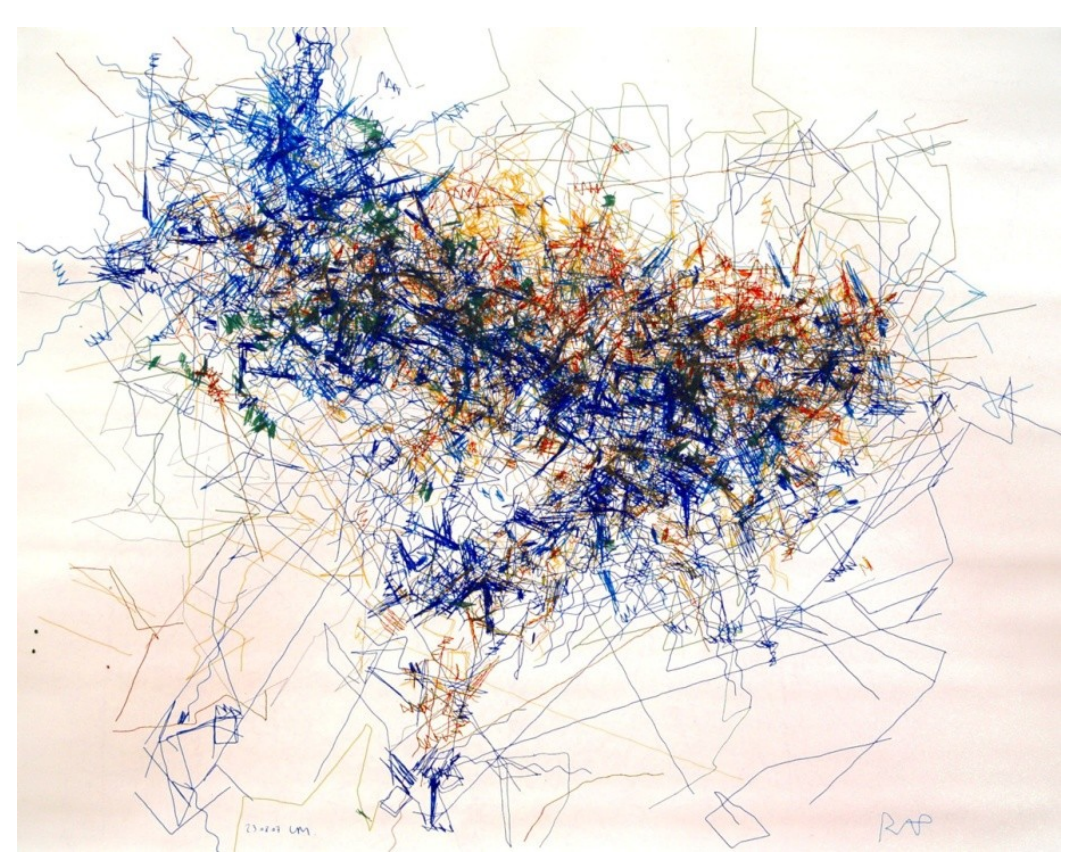

Figure 4. 230807, ink on canvas, $130 \times 180 \mathrm{~cm}$. C Leonel Moura.

\section{Emergence}

Central in recent studies, from Steven Johnson "Emergence" (2001) to Manuel DeLanda "Philosophy and Simulation" (2011), just to mention two seminal books a decade apart, the concept of Emergence is still rather difficult to grasp. In short, it shows how complex systems and patterns appear from simple rules and interactions. Common to physics and biology the concept is also applied to artificial intelligence and robotics. Consider, for example, swarm behavior, in which multiple agents interacting with each other and the environment, in a rather haphazard way, may generate order. What is less clear is the way in which these mechanics can produce a novel behavior independent from the set of rules and the intention of the human that implements and starts the process. Namely, it is difficult to determine when control becomes out of control [as Kevin Kelly explores in his now classic 1994 book Out of Control].

For some Emergence is just a deterministic mechanism. The set of rules or initial conditions determines the behavior and unpredictability is an emergent property of a system that is predictable on a lower level. This view de- 
preciates other important components of an emergent process ${ }^{1}$ such as randomness, interaction and environment. In addition, a complex system cannot be understood by examining its individual parts ${ }^{2}$.

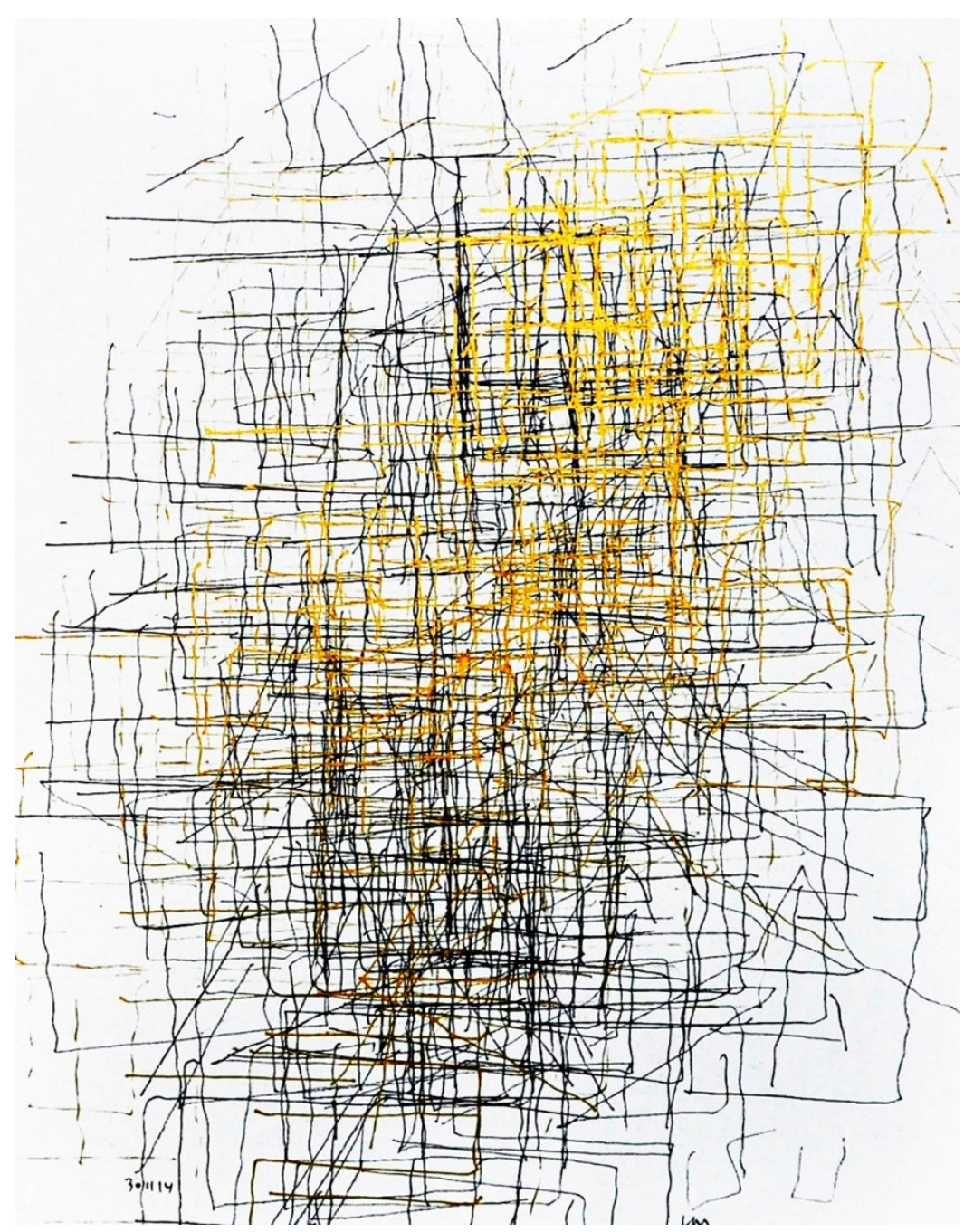

Figure 5. The abstract matrix, 301114, ink and acrylic on canvas, 81 x $61 \mathrm{~cm}$. (C) Leonel Moura.

\footnotetext{
${ }^{1}$ At least when applied to the kind of Emergence present in the swarm of my painting robots.

${ }^{2}$ For this see Dennett's concept of intentional emergence as the main property of complex systems.
} 


\section{Machine Art}

With the rise of computers Digital Art was the product of an artificial "language" used to implement routines, to trigger behaviors and to run algorithms inside machines. The distinction between objective and non-objective has become fuzzy as computers are radically objective but work and produce outputs without any reference to the real world.

The use of computers to make art was initially a subsidiary product of this new language. Artists used computers to generate processes and images that relate mainly to the inner architecture of the machines. Through rules, protocols and algorithms computers create processes and images as the result of complex calculations. The process is so clearly an abstraction of reality that its outputs are usually referred to as virtual.

In this new context, art appeared as the result of experimenting with automated algorithms, often described as Computer or Digital Art. In this kind of art the opposition to the objective or the figurative is not relevant. This art is abstract even when it depicts well-recognized objects or figures ${ }^{3}$.

With the advent of machines as thinking devices able to perform tasks based on their own discretion, a particular form of intelligence, coined artificial intelligence, was developed, and "computer art" took a new turn, in which complexity is ubiquitous.

Complexity is not a cumulative capacity, but it gives rise to the possibility to simulate bio-inspired and emergent artificial systems. The computer originates what is now known as artificial life, that is, organisms that live inside machines or explore the real world in the form of autonomous robots.

From this new field of exploration was born a new kind of art which is fundamentally autonomous, self-organized and emergent.

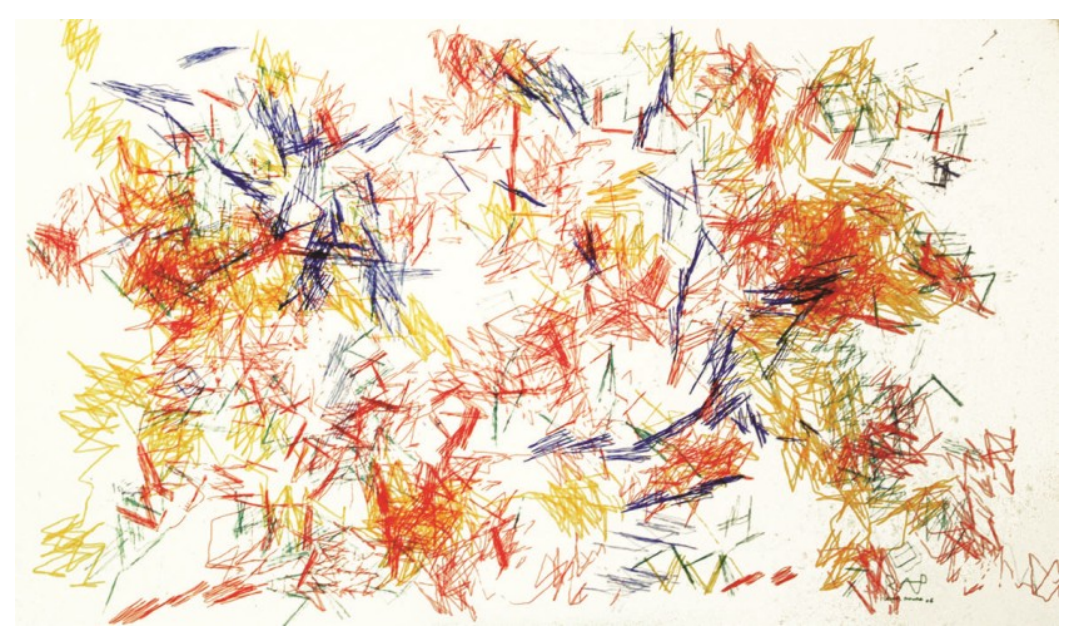

Figure 6. 200906, acrylic on canvas, $90 \times 120 \mathrm{~cm}$. (C) Leonel Moura.

3 As is the case of Harold Cohen's work. 


\section{Stigmergy}

Based on ants and other social insect's studies, I have tried to reproduce artificially a similar emergent behavior in a robot swarm. These insects communicate among themselves through chemical messages, pheromones, with which they produce certain patterns of collective behavior, such as following a trail, cleaning up, repairing and building nests, defense and attack or territory conquest. Despite pheromones not being the exclusive way of communication among these insects (the touch of antennas in ants or the dance in bees are equally important), pheromonal language produces complex cognition via bottom-up procedures. Pheromone expression is dynamic, making use of increments and decrements, positive and negative feedbacks. Messages are amplified when pheromone is reinforced, and lose "meaning" when breeze disperses it. It is also an indirect form of communication, called stigmergy by Grassé, from the Greek stigma/sign and ergon/action. Between the individual who places the message and the one who is stimulated by it, there is no proximity or direct relation.

Following these principles, we have replaced pheromone by color. The marks left by one robot triggers a pictorial action on other robots. Through this apparent random mechanism, abstract paintings are generated, which reveal well-defined shapes and patterns. These robots create abstract paintings that seem at first sight just random doodles, but after some reflexive observation color clusters and patterns become patent. Through the recognition of the color marks left by one robot, the others react by reinforcing certain color spots. The process is thus everything but arbitrary.

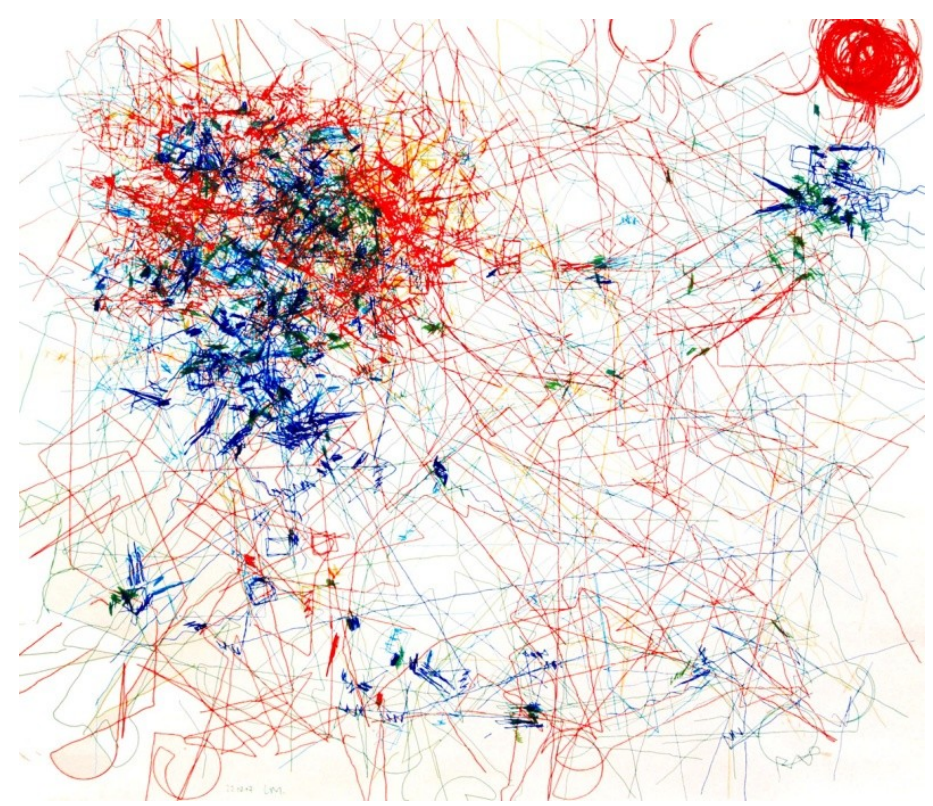

Figure 7. 220807, 2007, ink on canvas, 150 x $170 \mathrm{~cm}$. (C) Leonel Moura. 


\section{Conclusion}

Painting robots were created to paint. Not a specific painting but their own paintings. The essential of their creations stems from the machine's own interpretation of the world and not from its human description. No previous plan, fitness, aesthetic taste or artistic model is induced. These robots are machines dedicated to their art.

Such an endeavour addresses some of the most critical ideas in art, robotics and artificial intelligence. Today we understand intelligence as a basic feedback mechanism. If a system, any system, is able to respond to a certain stimulus in a way that it changes itself or its environment we can say that some sort of intelligence is present. 'Sheer' intelligence is therefore something that doesn't need to refer to any kind of purpose, target or quantification. It may plainly be an interactive mechanism of any kind, with no other objective than to process information and to react in accordance to available output capabilities.

Hence and although the starting point was bio-inspiration, in particular modeling social insect's emergent behavior, the idea was to construct machines able to generate a new kind of art with a minimum of fitness constraints, optimization parameters or real life simulation. It is the simple mechanism of feedback, emergence and stigmergy that is at work here.

These artistic robots are singular beings, with a particular form of intelligence and a kind of creativity all their own. They make art as other species build nests, change habitats or create social affiliations. But since we, humans, are for the time being the only pensive observers, the relation between machine art and human aesthetics principles is here the central issue. Many people appreciate these robot paintings, probably because we humans seem to gladly embrace fractal and chaotic structures. But, more than shapes and colors, what some of us really value in this idea, and its associated process, is the fact that it questions some of our strongest cultural convictions. Actually art was supposed to be an exclusive practice of mankind. In this sense, the robot paintings are a provocative conceptual art that problematizes the boundaries of art as we know it.

\section{References}

BECKERS, Ralph, Owen E. Holland, and Jean-Louis Deneubourg (1994). "From Local to Global Tasks: Stigmergy and Collective Robotics." Artificial Life IV: Proceedings of the Fourth International Workshop on the Synthesis and Simulation of Living Systems. Ed. Rodney Brooks. Cambridge, MA: MIT Press. 181-189.

BONABEAU, Eric, Marco Dorigo, and Guy Theraulaz (1999). Swarm Intelligence: From Natural to Artificial Systems. New York: Oxford University Press. 
BROOKS, Rodney A. (2002). Flesh and Machines: How Robots Will Change Us. New York: Pantheon Books.

DeLANDA, Manuel (2011). Philosophy and Simulation: The Emergence of Synthetic Reason. London: Continuum.

DENNETT, Daniel (2009). "Intentional Systems Theory." Inside: Arte e Ciência. Lisboa: Editora LxXL. 58-81.

GRASSÉ, Pierre-Paul. (1959). "La réconstruction du nid et les coordinations inter-individuelles chez Bellicositermes Natalienses et Cubitermes Sp. La théorie de la stigmergie: Essai d'interpretation des termites constructeurs." Insectes Sociaux, Tome VI.1 : 41-81.

JOHNSON, Steven (2001). Emergence: The Connected Lives of Ants, Brains, Cities, and Software. New York: Scribner.

KELLY, Kevin (1994). Out of Control: The New Biology of Machines, Social Systems, and the Economic World. New York: Basic Books.

LANGTON, Christopher G., ed. (1987). Artificial Life: Proceedings of an Interdisciplinary Workshop on the Synthesis and Simulation of Living Systems. New York: Addison-Wesley.

MOURA, Leonel and Henrique Garcia Pereira (2004). Symbiotic Art: Man + Robots. Lyon : Institut d'Art Contemporain.

SHANKEN, Edward A. (2001). "Art in the Information Age: Technology and Conceptual Art." Invisible College: Reconsidering "Conceptual Art". Ed. Michael Corris. Cambridge: Cambridge University Press. 